\title{
HOW I GROW: Months Five and Six ${ }^{1}$
}

Millie Ferrer, Keith Gouin, and Anne M. Fugate ${ }^{2}$

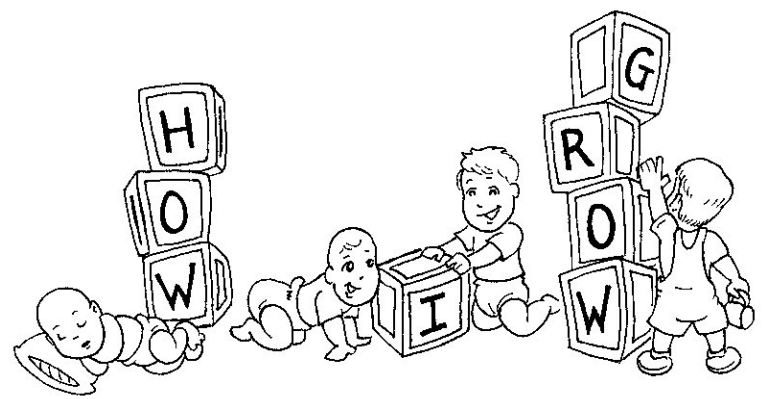

Welcome to another fascinating stage in your baby's development. At this age, babies are very happy and sociable, and much more physically active. You will see your baby's interest in his surroundings grow. Your baby will respond more to people and objects. What a great time to be a parent! Your baby is developing a strong curiosity about the world around him.

Your baby needs a stimulating world to interact with. Leaving him in a crib for many hours alone is not healthy. Make sure he has plenty of interesting and safe objects to play with. Talk to him, read to him, and keep him near you as you go through your daily routines.

Quickly and warmly, respond to his cries. Do not be afraid to hold him as much as you want. Research shows that babies who receive the attention they need will actually grow to be more independent through time. Experts agree that it is impossible to spoil a six-month-old baby. Parents who lovingly attend to their baby's needs help him develop physically, socially, emotionally, and intellectually.

\section{Physical Development}

At five months your baby is becoming much stronger and enjoys exercising her arms and legs. She will kick her feet in the air and use her arms to move herself on her belly, making circles. Play games with her to reinforce her physical development. For example, take your baby's feet in your hands and play "bicycling." You can also hold her arms out in front and touch each hand to the opposite foot. Make up a simple song while you play these games.

Your baby will want to practice rolling over. This is a perfect chance to have fun with her and talk about how big she is getting and how beautifully she is developing. Offer as much assistance as she needs to roll from stomach to back or from back to stomach. You can make up many games like this, and each one will cause your baby to laugh and giggle.

Your baby is actively learning about her world through touch and taste. She will begin to put

1. This document is FCS2219, one of a series of the Department of Family, Youth and Community Sciences, Florida Cooperative Extension Service, University of Florida, UF/IFAS, Gainesville, FL 32611. First published: August 2003 . Reviewed by Meredith Taylor, county extension director and extension agent IV, Live Oak; and Gayle Whitworth, extension agent I, Cocoa, FL. Thanks to Jason Greene for creating the artwork in this fact sheet. Please visit the EDIS Web site at http://edis.ifas.ufl.edu

2. Millie Ferrer, Ph.D., professor; Keith L. Gouin, coordinator educational/training programs; and Anne M. Fugate, former coordinator educational/ training programs, Department of Family, Youth and Community Sciences, University of Florida, IFAS, Gainesville, FL 32611. 
everything in her mouth. She will even suck her toes. Do not be alarmed when she puts things in her mouth. This is perfectly natural. Just make sure that objects are clean and large enough that she will not choke on them. (Objects should be at least $1-1 / 2$ inches in every dimension.) Your baby will enjoy playing with and putting in her mouth safe items such as plastic nesting cups, rattles, squeeze toys, stuffed animals, and large and small blocks.

Six months marks an exciting phase for your baby's hand-eye coordination. She can now reach for different items using her eyes as a guide. Play a game with her by placing

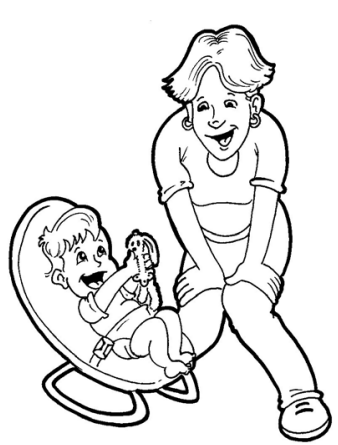
several objects on the floor and encouraging her to rake them up. As your baby's small muscle development continues, she will be able to reach for objects and pass them from one hand to the other. Play a game with her by giving her one object and then immediately giving her another object. Encourage her to transfer the previous object to the other hand. At six months your baby will probably be able to sit without support. She will also begin to try moving about on her own. She might try to pull herself up to a standing position or to get on her hands and knees to crawl around.

\section{Social Development}

One of the reasons babies are so much fun at this age is that they are very social and active. They enjoy being with people they know and they seem to always be busy doing one thing or the other. They may be playing with toys, staring at different objects around the room, babbling, or exercising their arms and legs. Babies can now play for longer periods of time. Your baby will enjoy lots of game time with you, playing "pat-a-cake," "peek-a-boo," and any other game you can make up.

\begin{tabular}{|c|c|}
\hline “Where's Baby?” & “This Little Pig" \\
\hline $\begin{array}{l}\text { Your child will love } \\
\text { to play "Where's } \\
\text { Baby?" } \\
\text { Hide your baby } \\
\text { under a sheet or a } \\
\text { blanket, while } \\
\text { saying, "Where's } \\
\text { ?" } \\
\text { Raise the blanket } \\
\text { and say, "There he } \\
\text { is!" }\end{array}$ & $\begin{array}{l}\text { Starting with the baby's } \\
\text { big toe, wiggle one toe } \\
\text { at a time as you say, } \\
\text { "This little piggy went to } \\
\text { market. This little piggy } \\
\text { stayed home. This little } \\
\text { piggy had roast beef. } \\
\text { This little piggy had } \\
\text { none. And, this little } \\
\text { piggy went wee-wee- } \\
\text { wee all the way home." }\end{array}$ \\
\hline
\end{tabular}

\section{Emotional Development}

Most of the time your baby is likely to be in a good mood, but she can display a range of emotions including fear, anger, distress, and sadness. For example, since your baby cannot walk yet, she can become frustrated or bored. She can now see across the room, but she cannot move around to explore the interesting things she sees. Your baby will cry to express her feelings. It is important

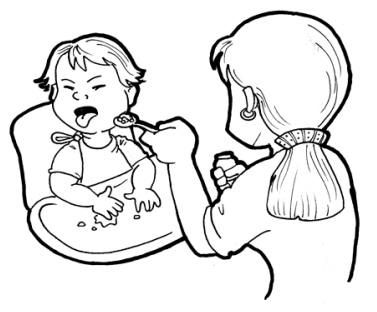
to be understanding about her feelings. Hold her close and gently describe what she is feeling and what the two of you will do about the situation.

It is crucial to make sure your baby has plenty of interesting and enjoyable things to do. Provide her with appropriate toys to play with while she lies on a blanket on the floor. Whenever possible, keep her near you as you work around the house so the two of you can interact. Remember to sing to her, read books to her, and play together often. By having an active world with caregivers who respond cheerfully and enthusiastically, she will be happier and less frustrated. 


\section{Intellectual Development}

Your baby's language development is rapidly increasing. You have probably noticed him babbling to himself as you enter the room and making all sorts of noises throughout the day. $\mathrm{He}$ may know his own name and turn to you when you call him. At this stage, he is learning where sounds come from. He will turn his head toward the source of a sound that has gained his attention. Play with him by hiding in different places in the room and calling out his name.

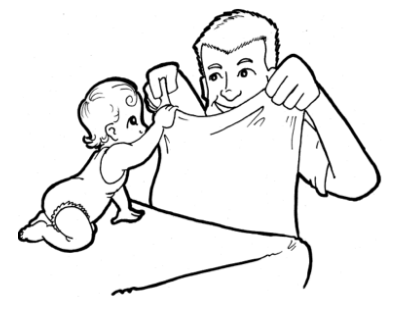

Your baby recognizes a number of different objects, even though he cannot talk yet. Continue to teach him about all the interesting things in his world. Talk to him about the pictures on the wall, the trees in the yard, and anything else he shows interest in.

During this stage your baby is very attuned to his environment. He is learning how things work. He studies different objects, fascinated by their shape, feel, and color. He turns things upside down to get a better view of them from different angles. Give him a variety of objects of different shapes and textures to examine and play with. Also, read him books that allow him to feel textures and shapes. For example, read him a book about animals with cut-out shapes through which he can feel fur or feathers.

\section{Parent Time}

Parenting is an ongoing process that requires patience. It can be stressful and demanding, and at times you may feel tired and grumpy. It is natural to want to be the best parent possible, but do not set unrealistic expectations for yourself. In addition to parenting, you may have many other responsibilities that seem to pull you in several different directions all at once. Do not add to the stress by getting down on yourself or neglecting your own needs. Remember that you are the key person in your baby's life. Your baby needs you to be healthy and happy, so take care of yourself by:

* Forgiving yourself

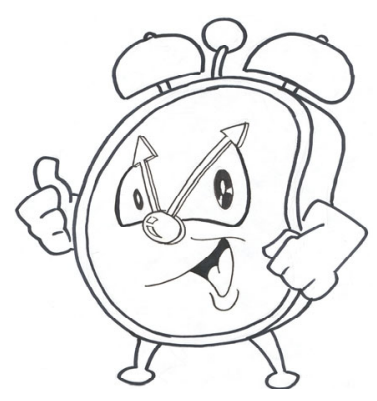
when you make mistakes.

* Asking for help when you need it--parenting is a hard job.

* Making time for relaxation.

As you continue to watch your baby grow and learn, notice the growth in your own life. Look at all of the things you have learned and the skills you have acquired. You are becoming a knowledgeable and competent parent. Even so, you are bound to make some mistakes like all parents do. If you lose your temper or become tired and unresponsive, do not be too hard on yourself. Forgive yourself and move on. In some ways, parents are no different than their children-parents cannot learn everything all at once.

\section{References}

Berk, Laura, E. 2002 . Infants and Children: Prenatal Through Middle Childhood $4^{\text {th }}$ Ed. Boston: Allyn \& Bacon.

Gottman, J. 1997. Raising an Emotionally Intelligent Child. New York: Simon \& Schuster.

Nelson, Patricia. 1995. Great Beginnings: A Series for Parents of Infants and Young Children. Retrieved March 26, 2002, from the University of Delaware, National Cooperative Extension We $\underline{\text { e site: }}$ http://ag.udel.edu/extension/fam/gb/gb-list.htm. 
O'Brien, S., E. Rooks-Weir, and S. Smith. 1996. Your Baby's First Year: Development During Month Five. University of Florida/IFAS Fact Sheet HE2036

O'Brien, S., E. Rooks-Weir, and S. Smith. 1996. Your Baby's First Year: Development During Month Six. University of Florida/IFAS Fact Sheet HE2037

University of Kentucky Cooperative Extension Service. 2002 . Keys to Great Parenting. Cuddle, Talk, and Read With Your Child. [Brochure].
What Grown-ups Understand About Child Development. Retrieved June 18, 2002, from the Zero to Three_Web_ site: http://www.zerotothree.org/Archive/survey.html" White, Burton, L. 1995. The New First Three Years of Life. New York: Simon \& Schuster.

White, Burton, L. 1994 . Raising a Happy Unspoiled Child. New York: Simon \& Schuster.

Your Baby: 5 Months. Retrieved March 27, 2002 from the Baby_ Center We http://www.babycenter.com/personal/1500.htmli 